\title{
Effect of straw size and microbial amendment of litter on certain litter quality parameters, ammonia emission, and footpad dermatitis in broilers
}

\author{
Mirjana Đukić Stojčić, Siniša Bjedov, Dragan Žikić, Lidija Perić, and Niko Milošević \\ University of Novi Sad, Faculty of Agriculture, Department of Animal Science, 21000 Novi Sad, Serbia \\ Correspondence to: Mirjana Đukić Stojčić (djukic@polj.uns.ac.rs)
}

Received: 17 July 2015 - Revised: 7 February 2016 - Accepted: 19 February 2016 - Published: 8 March 2016

\begin{abstract}
This study was conducted to evaluate the impact of litter amendment (microbiological product Micropan complex) and straw size (unchopped and chopped straw) on $\mathrm{pH}$, moisture level, ammonia emission, and footpad dermatitis in broilers. A total of 1200 1-day-old Ross 308 broilers were randomly allocated to four treatments $(2 \times 2$ factorial arrangement), with four replicates per treatment. Each replicate consisted of 75 ashatched birds per pen. The first factor consisted of wheat straw - chopped $(C)$ or unchopped $(U)-$ and the second factor was the litter amendment with (WM) or without (OM) Micropan ${ }^{\circledR}$ (enzymatic bacterial product Eurovix, USA). At 4, 5, and 6 weeks of the trial, the levels of ammonia concentration, moisture content, and pH of litter in each pen were measured. The foot pad lesions were evaluated at 21, 35, and 42 days of age. Broilers reared on chopped straw had significantly better leg condition as expressed by a smaller incidence and severity of footpad dermatitis. The $\mathrm{pH}$ value of litter was decreased and footpad quality was significantly improved by Micropan application in broilers kept on chopped and unchopped straw in the sixth week of age. There was no significant effect of Micropan application and straw size on ammonia emission in broiler housing.
\end{abstract}

\section{Introduction}

The quality of litter is a very significant factor in rearing broilers from the age of 1 day until slaughter because it affects health, productive parameters, carcass quality, and the welfare of broilers. According to Shepherd and Fairchild (2010), Grimes et al. (2002), and Bilgili et al. (2009), litter has several purposes, such as thermal insulation, moisture absorption, and acting as a protective barrier from the ground, and it allows bird scratching.

Several materials have been examined for use as broiler litter (rice hulls, ground corncobs, stump chips, pine sawdust, wood shavings, bark and chips, pine bark, clay sand, coconut husk, Guinea grass, newspaper, corn cob, wheat straw, ground rapeseed straw, and silage maize (Grimes et al., 2002; Sirri et al., 2007; Meluzzi et al., 2008; van Harn et al., 2012; Garcês et al., 2013). Each of these materials has its advantages and disadvantages, but the different particle size of these materials was seen to be the most important factor regarding paw quality and has been examined as a contributing factor in the development of footpad dermatitis (FPD) (Grimes et al., 2002).

While the most commonly used litter material in America is pine shavings, in Europe it is straw (Grimes et al., 2002; Shepherd and Fairchild, 2010). Serbia produces a lot of wheat and barley, whose straw is mostly used as a litter in broiler production. The availability and lower price of the straw compared to the wood shavings has led to a very intensive use of the straw as a bedding material, despite of its rather poor characteristics and negative influence on the development of FPD (Sirri et al., 2007; Meluzzi et al., 2008). Although there is some evidence that the particle size of the bedding has a significant effect on FPD (Grimes et al., 2002), further evidence is needed to confirm that the chopping of the straw could positively influence the condition of footpads.

Ammonia $\left(\mathrm{NH}_{3}\right)$ emissions from broiler litter have several disadvantages, and recommended concentrations are 25 to $50 \mathrm{ppm}$ in broiler houses (Miles et al., 2004). On the one hand, it causes environmental problems, while on the other hand, it has a negative effect on the health, welfare, and per- 
formance of birds (Miles et al., 2004; Atapattu et al., 2008; Stokstad, 2014). $\mathrm{NH}_{3}$ formation is directly controlled by factors such as $\mathrm{pH}$, temperature, and the moisture level in the litter (Elliott and Collins, 1982; Carr et al., 1990). Ammonia in the litter may contribute to further development of FPD (Haslam et al., 2006; Bilgili et al., 2009), although it does not seem to directly cause it (Martins et al., 2013). The bacteria-generated ammonia dissolves at a high moisture level (Mayne et al., 2007; Meluzzi et al., 2008; Allain et al., 2009; Nowaczewski et al., 2011) and forms an alkaline solution that acts as an irritant to the footpads.

Various litter amendments, such as chemicals - aluminium sulfate (Zhang et al., 2011), sodium bisulfate (Nagaraj et al., 2007; Li et al., 2012) - dietary manipulations (Ferguson et al., 1998; Eichner et al., 2007), zeolite (Li et al., 2008), microbiological preparation (Iwańczuk-Czernik et al., 2007), and a commercial ammonia binding agent (Lazarevic et al., 2014), are used to reduce litter moisture, $\mathrm{pH}$, and $\mathrm{NH}_{3}$ emission in boiler houses. Litter treatments with chemical or microbiological products have positive effects on litter condition by lowering the $\mathrm{pH}$ (Zhang et al., 2011), and reducing ammonia emission (Iwańczuk-Czernik et al., 2007; Li et al., 2008; Zhang et al., 2011) or litter moisture (IwańczukCzernik et al., 2007; Lazarevic et al., 2014).

This study was conducted to evaluate the impact of the straw size and the litter amendment (microbiological product - Micropan complex) on litter quality parameters (pH and moisture levels), ammonia emission, and footpad dermatitis in broilers.

\section{Materials and methods}

\subsection{Experimental design and husbandry}

The experiment was conducted at the experimental farm of the Faculty of Agriculture in Novi Sad, Serbia. A total of 1200 1-day-old Ross 308 broilers were randomly allocated to four treatments $(2 \times 2$ factorial arrangement), with four replicates per treatment. Each replicate consisted of 75 ashatched birds housed from 1-day old in floor pens measuring $5 \mathrm{~m}^{2}$ with stocking density of 15 birds $\mathrm{m}^{-2}$. The basic environmental parameters were in accordance with the demands of the hybrid used (Aviagen, 2014) with a lighting program of $18 \mathrm{~h}$ light and $6 \mathrm{~h}$ dark. Birds were vaccinated against Newcastle disease (NCD) and infectious bursal disease (IBD) as required by the country's veterinary authority. Feed and water were available ad libitum.

Broilers were reared to 42 days of age on a three-phase commercial feeding program consisting of a starter diet between 0 and 3 weeks $(22.00 \%$ crude protein, $12.65 \mathrm{ME}$ $\left.\mathrm{MJ} \mathrm{kg}^{-1}\right)$, a grower diet between 3 and 5 weeks $(21.00 \%$ crude protein, $13.20 \mathrm{ME} \mathrm{MJ} \mathrm{kg}^{-1}$ ), and a finisher diet in the sixth week (19.00\% crude protein, $\left.13.40 \mathrm{ME} \mathrm{MJ} \mathrm{kg}^{-1}\right)$.

The experimental treatments consisted of two factors. The first factor was related to the size of wheat straw - unchopped
$(U)$ or chopped $(C)$ - and the second factor was the litter treatment with an enzymatic bacterial product (Micropan ${ }^{\circledR}$ Simplex, Eurovix USA), which was applied on both chopped (WM) and unchopped straw (OM). The straw chopping was performed mechanically, and the length of the cut straw was ca. $20 \mathrm{~mm}$, with $2.5 \mathrm{~kg}$ of straw used per $\mathrm{m}^{2}$ of floor area. The product Micropan contains microorganisms and enzyme components and is used for the deodorization and sanification of poultry litter and manure. Micropan was applied to the surface of the litter according to the manufacturer's recommended rate $\left(1 \mathrm{~kg} 100 \mathrm{~m}^{-2}\right)$ at the beginning of the cycle, and further treatments took place on days 15 and 35 of the trial.

All procedures were conducted according to ethical norms proposed by the European Convention for the Protection of Vertebrate Animals Used for Experimental and Other Scientific Purposes, confirmed by Serbian authorities (Službeni glasnik RS - Međunarodni ugovori, 1/2010).

\subsection{Sample analysis}

\subsubsection{Litter measurements}

The litter moisture content was determined by the loss of weight after drying. Moisture was measured from the samples taken from the five different sites per pen (four from each corner and one from the centre). All five samples were mixed before analysis.In the lab, the pooled litter was weighed and dried at $105^{\circ} \mathrm{C}$ for $24 \mathrm{~h}$ and weighed again. The decrease in weight was recorded as moisture content (\%).

For determining the $\mathrm{pH}, 10 \mathrm{~g}$ litter samples from five areas of each pen were taken and immersed in $100 \mathrm{~mL}$ of distilled water. A weighted sample mat was then stirred for $15 \mathrm{~min}$ in a magnetic stirrer; thereafter, the sample was filtered through filter paper. After completion of filtration, the $\mathrm{pH}$ in the filtered liquid was measured using a $\mathrm{pH}$ meter (Inolab 720, WTW, Germany).

At 4, 5, and 6 weeks of the trial, the levels of ammonia concentration, moisture content, and $\mathrm{pH}$ of litter in each pen were measured. Ammonia concentration was determined by the method of Bilgili et al. (2009) using Dräger tubes with a measuring range from 5 to $70 \mathrm{ppm}$ (5/a) and a Dräger Accuro pump. The measurement was done in the following manner: a certain part of litter was covered with plastic containers $\left(40.5 \times 31.5 \times 12 \mathrm{~cm}\right.$, with a volume of $\left.0.15 \mathrm{~m}^{2}\right)$ for $60 \mathrm{~s}$, and after that, the concentration of ammonia was measured and read by inserting a measuring tube in the opening of the plastic containers located at the top centre.

\subsubsection{FPD scoring}

The incidence and severity of FPD were measured at 21, 35, and 42 days of age by the method described by Martrenchar et al. (2002), examining the left and right feet of birds. Birds with very dirty paws had their paws cleaned with a paper tissue before scoring. The footpad lesions were assigned to 
Table 1. Moisture content (\%) and $\mathrm{pH}$ of litter (unchopped or chopped straw) with or without addition of Micropanin in the fourth, fifth, and sixth week of age $(\bar{x} \pm \mathrm{SD})$.

\begin{tabular}{|c|c|c|c|c|c|c|c|c|}
\hline & \multirow[b]{2}{*}{ Weeks } & \multicolumn{2}{|c|}{ Unchopped straw } & \multicolumn{2}{|c|}{ Chopped straw } & \multicolumn{3}{|c|}{$P$} \\
\hline & & UOM & UWM & $\mathrm{COM}$ & CWM & Litter & Micropan & Interaction \\
\hline \multirow{6}{*}{$\begin{array}{l}\stackrel{0}{\Xi} \\
\stackrel{0}{0} \\
\stackrel{0}{\Sigma}\end{array}$} & Fourth week & $27.03^{\mathrm{a}}$ & $25.53^{\mathrm{a}}$ & $46.28^{\mathrm{b}}$ & $47.16^{b}$ & 0.001 & 0.945 & 0.791 \\
\hline & & \pm 4.60 & \pm 1.86 & \pm 11.27 & \pm 12.57 & & & \\
\hline & Fifth week & 38.67 & 38.26 & 43.14 & 45.31 & 0.169 & 0.826 & 0.748 \\
\hline & & \pm 8.51 & \pm 11.23 & \pm 4.30 & \pm 5.45 & & & \\
\hline & Sixth week & 48.43 & 48.96 & 47.44 & 51.76 & 0.819 & 0.542 & 0.633 \\
\hline & & \pm 12.25 & \pm 6.32 & \pm 5.98 & \pm 3.56 & & & \\
\hline \multirow{6}{*}{$\frac{\pi}{2}$} & Fourth week & 8.82 & 8.80 & 8.70 & 8.69 & 0.285 & 0.884 & 1.000 \\
\hline & & \pm 0.18 & \pm 0.18 & \pm 0.18 & \pm 0.23 & & & \\
\hline & Fifth week & $8.66^{\mathrm{b}}$ & $7.68^{\mathrm{a}}$ & $8.70^{\mathrm{b}}$ & $7.55^{\mathrm{a}}$ & 0.824 & 0.000 & 0.711 \\
\hline & & \pm 0.41 & \pm 0.32 & \pm 0.53 & \pm 0.14 & & & \\
\hline & Sixth week & 8.72 & 8.90 & 8.77 & 8.91 & 0.843 & 0.228 & 0.859 \\
\hline & & \pm 0.32 & \pm 0.18 & \pm 0.13 & \pm 0.29 & & & \\
\hline
\end{tabular}

a-b Means within the same rows with different superscripts are significantly different $(P<0.05)$; UOM: unchopped straw without addition of Micropan; UWM: unchopped straw with addition of Micropan; COM: chopped straw without addition of Micropan; CWM: chopped straw with addition of Micropan.

Table 2. Effect of straw size and litter amendment (Micropan) on ammonia concentration $\left(\mathrm{NH}_{3}\right.$, ppm) in the fourth, fifth, and sixth week of age $(\bar{x} \pm \mathrm{SD})$.

\begin{tabular}{lrrrrrrr}
\hline Treatment & \multicolumn{3}{c}{ Unchopped straw } & \multicolumn{2}{c}{ Chopped straw } & \multicolumn{2}{c}{$P$} \\
\hline Weeks & UOM & UWM & COM & CWM & Litter & Micropan & Interaction \\
\hline \multirow{2}{*}{ Fourth week } & 36.88 & 43.44 & 60.31 & 60.31 & 0.056 & 0.737 & 0.737 \\
& \pm 5.25 & \pm 21.83 & \pm 15.76 & \pm 26.46 & & & \\
Fifth week & 51.25 & 58.75 & 62.50 & 51.88 & 0.866 & 0.904 & 0.488 \\
& \pm 22.78 & \pm 34.25 & \pm 23.00 & \pm 18.64 & & & \\
Sixth week & 57.65 & 59.90 & 64.15 & 63.75 & 0.366 & 0.707 & 0.264 \\
& \pm 5.73 & \pm 20.42 & \pm 21.93 & \pm 30.63 & & & \\
\hline
\end{tabular}

UOM: unchopped straw without addition of Micropan; UWM: unchopped straw with addition of Micropan; COM: chopped straw without addition of Micropan; CWM: chopped straw with addition of Micropan.

one of four scores: no lesions (score 0), lesions in some areas $(<25 \%$ ) (score 1), lesions in wide areas (between 25 and $50 \%$ ) (score 2 ), and more than $50 \%$ lesion on the footpads (score 3). The mean score of FPD was calculated as the cumulative total of the lesion scores divided by the total number of birds examined.

\subsubsection{Statistical analyses}

Data were analysed by factorial analysis of variance (ANOVA) using the GLM (general linear model) procedure. Means were separated by a Duncan post hoc test using StatSoft computer package (STATISTICA 11, 2012). Results were considered significant when $P<0.05$.

\section{Results}

The mean values of the litter moisture content and $\mathrm{pH}$ for different groups is presented in Table 1. The moisture content was significantly lower in groups with unchopped straw in the fourth week of age, but towards the end of the trial this effect was lost. In the fifth and sixth week of age, there were no significant differences between groups in moisture content in the litter. In the same period, the application of Micropan did not affect the moisture content. At the fifth and sixth week of age, it was noticed that a crust formed on the surface of the litter treated with Micropan in both chopped and unchopped straw litter pens.

Measurement of $\mathrm{pH}$ in the fifth week of age indicated that the application of Micropan significantly reduced $\mathrm{pH}$ in both types of the straw (chopped and unchopped). However, in the fourth and sixth week of age, neither the size of the straw nor litter amendment influenced the $\mathrm{pH}$ value in the litter. 
Table 3. Effect of straw size and litter amendment (Micropan) on the incidence of foot pad dermatitis (FPD) in broilers at 3 weeks of age $(\bar{x} \pm \mathrm{SD})$.

\begin{tabular}{|c|c|c|c|c|c|c|c|c|c|c|c|}
\hline \multirow{3}{*}{$\begin{array}{l}\text { Treatment } \\
\text { Parameter } \\
\text { Lesions }\end{array}$} & \multicolumn{4}{|c|}{ Unchopped straw } & \multicolumn{4}{|c|}{ Chopped straw } & \multicolumn{3}{|c|}{$P$} \\
\hline & \multicolumn{2}{|c|}{ UOM } & \multicolumn{2}{|c|}{ UWM } & \multicolumn{2}{|c|}{$\mathrm{COM}$} & \multicolumn{2}{|c|}{ CWM } & \multirow{7}{*}{ 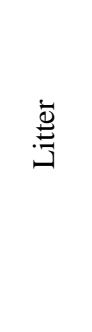 } & \multirow{7}{*}{ 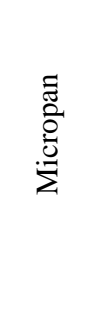 } & \multirow{7}{*}{ 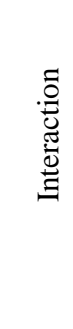 } \\
\hline & No. & $\%$ & No. & $\%$ & No. & $\%$ & No. & $\%$ & & & \\
\hline 0 & 4 & 1.99 & 9 & 4.57 & 32 & 15.85 & 48 & 24.87 & & & \\
\hline 1 & 151 & 74.75 & 107 & 54.31 & 143 & 70.79 & 136 & 70.46 & & & \\
\hline 2 & 47 & 23.26 & 65 & 32.99 & 27 & 13.36 & 9 & 4.66 & & & \\
\hline 3 & 0 & 0.00 & 16 & 8.13 & 0 & 0.00 & 0 & 0.00 & & & \\
\hline Total & 202 & 100.00 & 197 & 100.00 & 202 & 100.00 & 193 & 100.00 & & & \\
\hline $\begin{array}{l}\text { Average } \\
\text { score }\end{array}$ & & $\begin{array}{l}21^{\mathrm{c}} \\
.45\end{array}$ & & $\begin{array}{l}44^{\mathrm{d}} \\
0.70\end{array}$ & & $\begin{array}{l}97^{b} \\
0.54\end{array}$ & & $\begin{array}{l}79^{\mathrm{a}} \\
0.50\end{array}$ & 0.000 & 0.478 & 0.000 \\
\hline
\end{tabular}

${ }^{\mathrm{a}-\mathrm{d}}$ Means within the same rows with different superscripts are significantly different $(P<0.05)$; COM: chopped straw without addition of Micropan; CWM: chopped straw with addition of Micropan; UOM: unchopped straw without addition of Micropan; UWM: unchopped straw with addition of Micropan.

Table 4. Effect of straw size and litter amendment (Micropan) on the incidence of foot pad dermatitis (FPD) of broilers at 5 weeks of age $(\bar{x} \pm \mathrm{SD})$.

\begin{tabular}{|c|c|c|c|c|c|c|c|c|c|c|c|}
\hline \multirow{3}{*}{$\begin{array}{l}\text { Treatment } \\
\text { Parameter } \\
\text { Lesions }\end{array}$} & \multicolumn{4}{|c|}{ Unchopped straw } & \multicolumn{4}{|c|}{ Chopped straw } & \multicolumn{3}{|c|}{$P$} \\
\hline & \multicolumn{2}{|c|}{ UOM } & \multicolumn{2}{|c|}{ UWM } & \multicolumn{2}{|c|}{$\mathrm{COM}$} & \multicolumn{2}{|c|}{ CWM } & \multirow{7}{*}{ 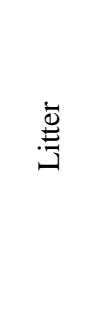 } & \multirow{7}{*}{$\begin{array}{l}\tilde{\Xi} \\
\stackrel{0}{0} \\
\stackrel{0}{0} \\
\dot{\Sigma}\end{array}$} & \multirow{7}{*}{ 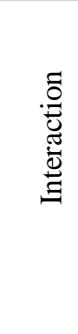 } \\
\hline & No. & $\%$ & No. & $\%$ & No. & $\%$ & No. & $\%$ & & & \\
\hline 0 & 14 & 7.07 & 12 & 5.83 & 17 & 7.91 & 25 & 12.20 & & & \\
\hline 1 & 49 & 24.75 & 66 & 32.04 & 90 & 41.86 & 75 & 36.59 & & & \\
\hline 2 & 66 & 33.33 & 70 & 33.98 & 62 & 28.84 & 44 & 21.46 & & & \\
\hline 3 & 69 & 34.85 & 58 & 28.16 & 46 & 21.40 & 61 & 29.76 & & & \\
\hline Total & 198 & 100.00 & 206 & 100.00 & 215 & 100.00 & 205 & 100.00 & & & \\
\hline $\begin{array}{l}\text { Average } \\
\text { score }\end{array}$ & & $\begin{array}{l}95^{\mathrm{c}} \\
0.93\end{array}$ & & $\begin{array}{l}84^{\text {bc }} \\
0.90\end{array}$ & & $\begin{array}{l}63^{\mathrm{a}} \\
0.90\end{array}$ & & $\begin{array}{l}68^{\mathrm{ab}} \\
1.02\end{array}$ & 0.000 & 0.625 & 0.209 \\
\hline
\end{tabular}

${ }^{a-c}$ Means within the same rows with different superscripts are significantly different $(P<0.05)$; UOM: unchopped straw without addition of Micropan; UWM: unchopped straw with addition of Micropan; COM: chopped straw without addition of Micropan; CWM: chopped straw with addition of Micropan.

There were no significant interactions between litter size and Micropan application at any age of the birds.

Table 2 shows the effect of straw size and Micropan on ammonia concentration $\left(\mathrm{NH}_{3}, \mathrm{ppm}\right)$ in the fourth, fifth, and sixth week of age. In all 3 observed weeks ammonia concentration was not significantly influenced by the addition of Micropan or the straw size, and the interaction between litter size and Micropan was not significant.

Footpad lesions were evaluated at 21,35, and 42 days of age. The incidence and severity of footpad lesions of broilers by weeks are presented in Tables 3, 4, and 5 . The influence of the litter type on the average FPD score was highly significant $(P<0.01)$. Broiler chickens kept on chopped straw had significantly better paw condition as expressed by a smaller incidence and severity of FPD at all weeks of age. On the other hand, addition of Micropan showed a significant effect on FPD score $(P<0.01)$ only at 6 weeks of age. The inter- action of litter and Micropan was significant only at 3 weeks of age. The addition of Micropan significantly reduced the incidence of FPD in broilers raised on chopped straw but not on the unchopped straw as revealed by the significant interaction.

\section{Discussion}

Several studies have shown that FPD can be induced by litter moisture alone (Mayne et al., 2007; Meluzzi et al., 2008; Allain et al., 2009; Nowaczewski et al., 2011). On the other hand, Eichner et al. (2007) and Nagaraj et al. (2007) have found no significant correlation between litter moisture and the incidence and severity of FPD, which coincides with our results. In the fifth week of age, the application of Micropan led to the lowering of the $\mathrm{pH}$ with both types litter (chopped and unchopped). Although the $\mathrm{pH}$ of the litter treated with 
Table 5. Effect of straw size and litter amendment (Micropan) on the incidence of foot pad dermatitis (FPD) in broilers at 6 weeks of age $(\bar{x} \pm \mathrm{SD})$.

\begin{tabular}{|c|c|c|c|c|c|c|c|c|c|c|c|}
\hline \multirow{3}{*}{$\begin{array}{l}\text { Treatment } \\
\text { Parameter } \\
\text { Lesions }\end{array}$} & \multicolumn{4}{|c|}{ Unchopped straw } & \multicolumn{4}{|c|}{ Chopped straw } & \multicolumn{3}{|c|}{$P$} \\
\hline & \multicolumn{2}{|c|}{ UOM } & \multicolumn{2}{|c|}{ UWM } & \multicolumn{2}{|c|}{$\mathrm{COM}$} & \multicolumn{2}{|c|}{ CWM } & \multirow{7}{*}{ : } & \multirow{7}{*}{$\begin{array}{l}\tilde{\Xi} \\
\stackrel{\tilde{O}}{0} \\
\stackrel{0}{\Sigma}\end{array}$} & \multirow{7}{*}{ 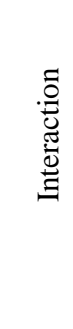 } \\
\hline & No. & $\%$ & No. & $\%$ & No. & $\%$ & No. & $\%$ & & & \\
\hline 0 & 5 & 2.69 & 3 & 1.48 & 3 & 1.50 & 26 & 14.44 & & & \\
\hline 1 & 57 & 30.65 & 86 & 42.36 & 65 & 32.50 & 77 & 42.78 & & & \\
\hline 2 & 57 & 30.65 & 70 & 34.48 & 66 & 33.00 & 47 & 26.11 & & & \\
\hline 3 & 67 & 36.02 & 44 & 21.67 & 66 & 33.00 & 30 & 16.67 & & & \\
\hline Total & 186 & 100.00 & 203 & 100.00 & 200 & 100.00 & 180 & 100.00 & & & \\
\hline $\begin{array}{l}\text { Average } \\
\text { score }\end{array}$ & \multicolumn{2}{|c|}{$\begin{array}{l}1.94^{\mathrm{c}} \\
\pm 0.92\end{array}$} & \multicolumn{2}{|c|}{$\begin{array}{l}1.76^{\mathrm{b}} \\
\pm 0.80\end{array}$} & \multicolumn{2}{|c|}{$\begin{array}{l}1.71^{\mathrm{b}} \\
\pm 0.84\end{array}$} & \multicolumn{2}{|c|}{$\begin{array}{l}1.47^{\mathrm{a}} \\
\pm 0.93\end{array}$} & 0.000 & 0.000 & 0.530 \\
\hline
\end{tabular}

a-c Means within the same rows with different superscripts are significantly different $(P<0.05)$; UOM: unchopped straw without addition of Micropan; UWM: unchopped straw with addition of Micropan; COM: chopped straw without addition of Micropan; CWM: chopped straw with addition of Micropan.

Micropan was significantly lower in week 5 compared to untreated groups, this did not lead to the lowering of concentration of ammonia in the litter. That could be explained by the fact that the moisture content in the litter was very high in all groups, and $\mathrm{NH}_{3}$ formation is directly controlled by the moisture level besides the temperature and $\mathrm{pH}$ (Elliott and Collins, 1982; Carr et al., 1990).

Chickens reared on chopped straw had lower FPD scores. In the fifth week of age, the application of Micropan led to the lowering of $\mathrm{pH}$ with both types of litter (chopped and unchopped).

Crust formation at the surface of the litter treated with Micropan was observed from the fourth to sixth week of the trial. It is assumed that this led to a lower FPD score in chickens reared on unchopped straw as well. The crust was dry; thus, the foot pads were cleaner, but the bottom below the litter was wetter than the bottom of the pen without Micropan. The samples used for measuring the moisture content of the litter came from the top to the bottom of the litter layer. Most likely this was the reason why there is no significant difference in moisture levels between all observed groups

This study, as well as investigations by Bilgili et al. (2009) and Shepherd and Fairchild (2010), confirms that the particle size of litter material has an important role in the development of FPD because broiler chickens kept on chopped straw had lower FPD score at all ages analysed. Hester et al. (1997) also found that the highest incidence of FPD was with the coarse-particle board treatment.

In all 3 observed weeks, ammonia concentration was not significantly influenced by the addition of Micropan or straw size. These results are not consistent with the research of Jeppsson (1999), who pointed out that chopped straw emits considerably less ammonia than long straw in a building for young cattle. Our results agree with the results of Slobodzian-Ksenicz and Kuczyński (2002), who did not find any significant effect of litter type (long straw, wood shavings, or chopped straw) on ammonia emission in turkey housing.

In this experiment ammonia concentration varied from 36.88 to $62.50 \mathrm{ppm}$ at the surface of the litter in all groups. These concentrations were less than the emission rates found by Bilgili et al. (2009) (65 to $105 \mathrm{ppm}$ ) and greater than the emission rates reported by Do et al. (2005) (up to $39 \mathrm{ppm}$ ) and Witkowska et al. (2006) (up to $31.2 \mathrm{ppm}$ ). IwańczukCzernik et al. (2007) state that the application of a microbiological preparation (Biosan-GS) and a disinfectant (Lubisan) in broilers reduced ammonia concentration in litter. Based on the ammonia levels observed in this study, this hypothesis cannot be confirmed.

\section{Conclusion}

A study was conducted to evaluate the impact of Micropan (microbiological product) application and the straw size on ammonia emission and footpad dermatitis in broilers. The following conclusions were drawn:

- Broilers reared on chopped straw had significantly better leg condition as expressed by a smaller incidence and severity of FPD at 3 and 5 weeks of age.

- Litter pH was decreased by Micropan application in broilers kept on chopped and unchopped straw in the fifth week of age

- There was no significant effect of Micropan application and straw size on ammonia emission in broiler housing.

- The footpad quality was significantly improved by Micropan application at 6 weeks of age. 
- Further studies on commercial farming are needed to determine the effects of litter amendments and the straw size on footpad dermatitis in broilers.

Acknowledgements. This work has been funded by the Ministry of Education, Science and Technology Development Republic of Serbia as a part of the Project No. TR 31033.

Edited by: K. Wimmers

Reviewed by: two anonymous referees

\section{References}

Allain, V., Mirabito, L., Arnould, C., Colas, M., Bouquin, S. L., Lupo, C., and Michel, V.: Skin lesions in broiler chickens measured at the slaughterhouse: Relationships between lesions and between their prevalence and rearing factors, Brit. Poultry Sci., 50, 407-417, 2009.

Atapattu, N. S. B. M., Senaratna D., and Belpagodagamage, U. D.: Comparison of ammonia emission rates from three types of broiler litters, Poultry Sci., 87, 2436-2440, 2008.

Aviagen: Ross broiler management handbook 2014, available at: http://en.aviagen.com/assets/Tech_Center/Ross_Broiler/ Ross-Broiler-Handbook-2014i-EN.pdf (last access: 25 February 2016), 2014.

Bilgili, S. F., Alley, M. A., Hess, J. B., Blake, J. P., Macklin, K. S., and Sibley, J. L.: Influence of bedding material on footpad dermatitis in broiler chickens, J. Appl. Poultry Res., 18, 583-589, 2009.

Carr, L. E., Wheaton, F. W., and Douglass, L. W.: Empirical models to determine ammonia concentrations from broiler chicken litter, Trans. ASAE, 33, 1337-1342, 1990.

Do, J. C., Choi, I. H., and Nahm, K. H.: Effects of Chemically Amended Litter on Broiler Performances, Atmospheric Ammonia Concentration, and Phosphorus Solubility in Litter, Poultry Sci., 84, 679-686, 2005.

Eichner, G., Vieira, S. L., Torres, C. A., Coneglian, J. L. B., Freitas, D. M., and Oyarzabal, O. A.: Litter moisture and foot pad dermatitis as affected by diets formulated on an all-vegetable basis or having the inclusion of poultry by-product, J. Appl. Poultry Res., 16, 344-350, 2007.

Elliott, H. A. and Collins, N. E.: Factors affecting ammonia release in broiler houses, Trans. Am. Soc. of Agric. Eng., 25, 413-418, 1982.

Ferguson, N. S., Gates, R. S., Taraba, J., Cantor, A. H., Pescatore, A. J., Ford, M. J., and Burnham, D. J.: The effect of dietary crude protein on growth, ammonia concentration and litter composition in broiler, Poultry Sci., 71, 1481-1487, 1998.

Garcês, A., Afonso, S. M. S., Chilundo, A., and Jairoce, C. T. S.: Evaluation of different litter materials for broiler production in a hot and humid environment: 1 . litter characteristics and quality, J. Appl. Poultry Res., 22, 168-176, 2013.

Grimes, J. L., Smith, J., and Williams, C. M.: Some alternative litter materials used for growing broilers and turkeys, World Poultry Sci. J., 58, 515-526, 2002.

Haslam, S. M., Brown, S. N., Wilkins, L. J., Kestin, S. C., Warriss, P. D.. and Nicol, C. J.: Preliminary study to examine the utility of using foot burn or hock burn to assess aspects of housing conditions for broiler chicken, Brit. Poultry Sci., 47, 13-18, 2006.

Hester, P. Y., Cassens, D. L., and Bryan, T. A. The applicabilityof particleboard residue as a litter material for male turkeys, Poultry Sci., 76, 248-255, 1997.

Iwańczuk-Czernik, K., Witkowska, D., Sowinska, J., Wójcik, A., and Mituniewicz, T.: The effect of a microbiological and a disinfecting preparation on the physical an chemical properties of litter and the results of broiler chicken breedin, Polish J. Natural Sci. 22, 395-406, 2007.

Jeppsson, K. H.: Volatilization of ammonia in deep-litter systems with different bedding materials for young cattle, J. Agr. Eng. Res., 73, 49-57, 1999. It is added as a comment in the reference list, at the place where it should alphabetically appear.

Lazarevic, M., Resanovic, R., Vucicevic, I., Kocher, A., and Moran, C. A.: Effect of feeding a commercial ammonia binding product De-Odorase $^{\mathrm{TM}}$ on broiler chicken performance, J. Appl. Anim. Nutr. 2, 6 pp., 2014.

Li, H., Xin, H. Burns, R. T., and Liang, Y.: Reduction of ammonia emissions from stored laying hen manure through topical application of zeolite, Al+Clear, Ferix-3, or poultry litter treatment, J. Appl. Poultry Res., 17, 421-431, 2008.

Li, H., Lin, C., Collier, S., White-Hansen, S., and Brown, W.: Assessment of repeated litter amendment application on ammonia reduction, ASABE Meeting Paper No. 12-1337336, 2012.

Martins, R. S., Hötzel, M. J., and Poletto, R.: Influnce of in - house composting of reused litter on litter quality, ammonia volatilisation and incidence of broiler foot pad dermatitis. Brit. Poultry Sci., 54, 669-676, 2013.

Martrenchar, A., Boilletot, E., Huonnic, D., and Pol, F.: Risk factors for foot-pad dermatitis in chicken and turkey broilers in France, Prev. Vet. Med., 52, 213-226, 2002.

Mayne, R. K., Else, R. W., and Hocking, P. M.: High littermoisture alone is sufficient to cause footpad dermatitis in growing turkeys, Brit. Poultry Sci, 48, 538-545, 2007.

Meluzzi, A., Fabbri,C., Folegatti,E., and Sirri, F.: Survey ofchicken rearing conditions in Italy: Effects of litter quality andstocking density on productivity, foot dermatitis and carcase injuries, Brit. Poultry Sci. 49, 257-264, 2008.

Miles, D. M., Branton, S. L., and Lott, B. D.: Atmospheric ammonia is detrimental to the performance of modern commercial broilers. Poultry Sci., 83, 1650-1654, 2004.

Nagaraj, M., Wilson, C. A. P., Saenmahayak, B., Hess, J. B., and Bilgili, S. F.: Efficacy of a litter amendment to reduce pododermatitis in broiler chickens, J. Appl. Poultry Res., 16, 255-261, 2007.

Nowaczewski, S., Rosiński, A., Markiewicz, M., and Kontecka, H.: Performance, foot-pad dermatitis and haemoglobin saturation in broiler chickens kept on different types of litter, Arch. Geflügelkd., 75, 132-139, 2011.

Shepherd, E. M. and Fairchild, B. D.: Footpad dermatitis in poultry, Poultry Sci., 89, 2043-2051, 2010.

Sirri, F., Minelli, G., Folegatti, E., Lolli, S., and Meluzzi, A.: Footdermatitis and productive traits in broiler chickens kept with differentstocking densities, litter types and light regimen, Ital. J. Anim. Sci., 6, 734-736, 2007.

Slobodzian-Ksenicz, O. and Kuczyński, T.: Effect of Litter Type on Ammonia Emission in Turkey Housing, Agricultural Engineer- 
ing International: the CIGR Journal of Scientific Research and Development, BC 01 006, IV, 2002.

STATSOFT, STATISTICA 11: 2012: Copyright $^{\circledR}$ StatSoft. available at: http://www.statsoft.com/ (last access: 1 March 2016), 2012.

Stokstad, E.: Ammonia pollution from farming may exact hefty health costs, Science, 343, p. 238, 2014.

van Harn, J., Aarnink, A. J. A., Mosquera, J., van Riel, J. W., and Ogink, N. W. M.: Effect of Bedding Material on Dust and Ammonia Emission from Broiler Houses, American Society of Agricultural and Biological Engineers, 55, 219-226, 2012.
Witkowska, D., Sowińska, J., Iwańczuk-Czernik, K., Mituniewicz, T., Wójcik, A., and Szarek, J.: The effect of a disinfectant on the ammonia concentration on the surface of litter, air and the pathomorphological picture of kidneys and livers in broiler chickens, Arch. Tierzucht, 49, 249-256, 2006.

Zhang, H., Hamilton, D. W., and Payne, J.: Using poultry litter as fertilizer, available at: http://www.poultrywaste.okstate.edu/files/ pss2246web.pdf (last access: 25 February 2016), 2011. 